\title{
SISTEM PENDUKUNG KEPUTUSAN UNTUK MENENTUKAN PEMAIN TERBAIK DALAM SATU MUSIM KOMPETISI SEPAKBOLA DENGAN MENGGUNAKAN METODE SIMPLE ADDITIVE WEIGHTING
}

\author{
Hendra Gunawan, Sugih Alamsyah \\ Program Studi Sistem Informasi \\ STMIK Indonesia Mandiri, Jl.Jakarta No.79 Bandung
}

\begin{abstract}
ABSTRAK
Pemain merupakan salah satu kunci penting demi berjalannya kompetisi sepakbola yang kompetitif dan berkualitas. Klub yang mengikuti kompetisi sepak bola harus cerdas dalam menentukan pemain-pemainnya, tidak mudah dalam menentukan pemain yang akan direkrut, harus melalui penilaian yang sistematis guna meminimalisir kesalahan. Untuk mendukung pihak pengambil keputusan, dirancang sebuah aplikasi sistem pendukung keputusan yang berbasis komputer (Computer Based Decision Support System) untuk mengurangi subjektifitas dalam menentukan pemain terbaik, sehingga keputusan yang dihasilkan lebih tepat, dan akurat.

Sistem pendukung keputusan ini akan dibangun dengan menggunakan metode Simple Additive Weighting (SAW), serta menggunakan bahasa pemrograman PHP dan MySQL untuk implementasinya.

Hasil penelitian ini dapat membantu, penyelenggara dalam menentukan pemain maupun klub terbaik dalam suatu kompetisi.
\end{abstract}

Kata Kunci : Sistem Pendukung Keputusan, Metode Simple Additive Weighting (SAW), Pemain Terbaik, Sepakbola.

\section{PENDAHULUAN}

Olahraga sepak bola merupakan olahraga yang paling digemari di seluruh dunia, khususnya di Indonesia (Wawan, dkk., 2017), namun di Indonesia sendiri implementasi teknologi pada olahraga sepak bola masih tertinggal dibanding negara-negara lain. Kompetisi sepak bola di Indonesia seringkali diwarnai hal-hal kontroversial, salah satunya dalam mengambil keputusan untuk menentukan pemain terbaik.

Penentukan pemain terbaik terkesan subyektif dan tidak dilakukan dengan pendekatan sistematis, oleh karena itu penggunaan teknologi informasi sebagai sarana untuk mendukung keputusan para pengambil keputusan sangat diharapkan agar keputusan yang dihasilkan sesuai dengan keinginan berbagai pihak yang terlibat dalam persepakbolaan di Indonesia. 
Terkait dengan permasalaan tersebut, penelitian ini berfokus pada pembangunan sistem pendukung keputusan untuk menentukan pemain terbaik menggunakan metode Simple Additive Weighting.

\subsection{Tujuan}

Tujuan penelitian adalah sebagai berikut :

1. Untuk membantu klub sepak bola dalam menentukan pemain yang akan direkrut.

2. Membuat aplikasi Sistem Pendukung Keputusan memilih pemain sepak bola terbaik menggunakan metode Simple Additive Weighting (SAW).

\subsection{Batasan Masalah}

Batasan masalah sebagai berikut :

1. Sistem pendukung keputusan yang dibuat mengacu hanya pada kompetisi sepak bola liga 1 Indonesia dalam 1 (satu) musim kompetisi.

2. Proses penyeleksian pemain terbaik berdasarkan kriteria-kriteria benefit dan cost yang telah ditentukan, mencakup aspek fairplay, kemampuan individu, dan kontribusi pada tim, dengan 5 (lima) penilaian bobot kriteria.

3. Sistem pendukung keputusan dibuat dengan menggunakan metode Simple Additive Weighting (SAW), aplikasi yang akan dibangun berbasis web dengan bahasa pemrograman PHP dan MySQL sebagai database.

\section{METODE PENELITIAN}

\subsection{Metode Pengembangan Perangkat Lunak}

Metode pengembangan perangkat lunak dalam penilitian ini menggunakan model waterfall menurut Rosa dan Salahudin (2018:29) dengan tahapan sebagai berikut : 


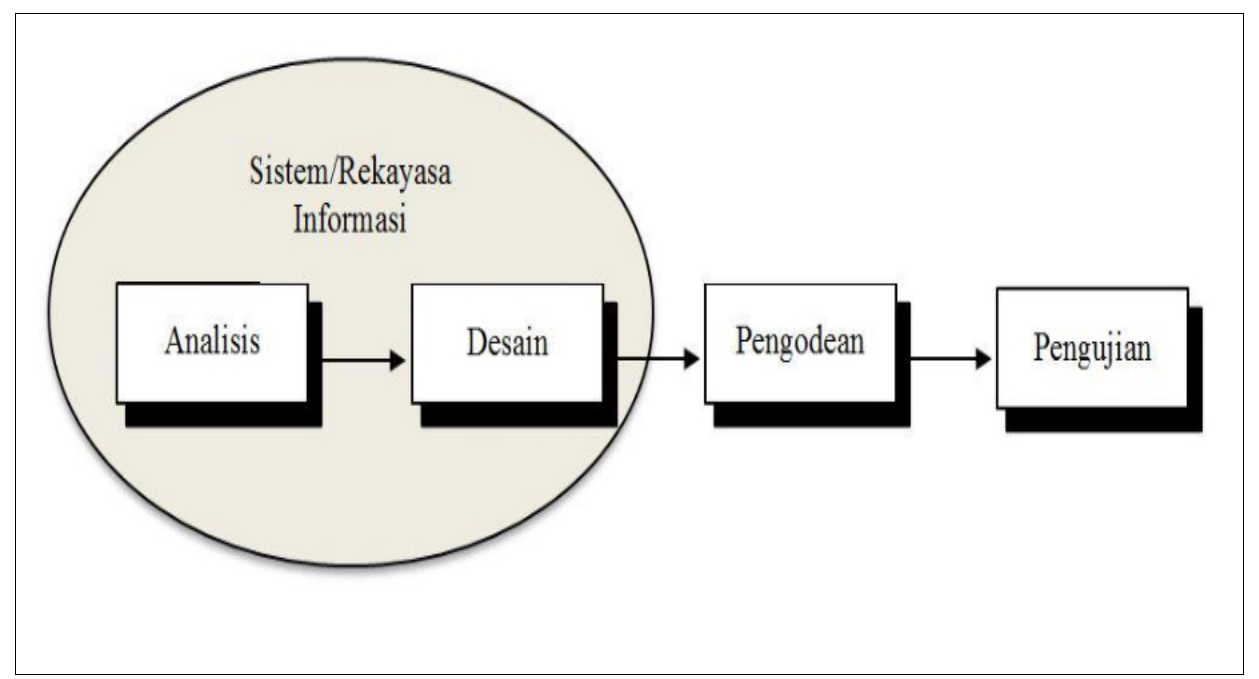

GAMBAR 1. Metode waterfall (Rosa dan Salahudin, 2018:29)

1. Analisis kebutuhan perangkat lunak

Pada tahap ini dilakukan proses pengumpulan kebutuhan secara intensif untuk mespesifikasikan kebutuhan perangkat lunak agar dapat dipahami perangkat lunak seperti apa yang dibutuhkan oleh user.

2. Desain

Desain perangkat lunak adalah proses multi langkah yang fokus pada desain pembuatan program perangkat lunak termasuk struktur data, arsitektur perangkat lunak, representasi antarmuka, dan prosedur pengodean. Tahap ini mentranslasi kebutuhan perangkat lunak dari tahap analisis kebutuhan ke representasi desain agar dapat diimplementasikan menjadi program pada tahap selanjutnya.

\section{Pembuatan kode program}

Desain harus ditranslasikan ke dalam program perangkat lunak. Hasil dari tahap ini adalah program komputer sesuai dengan desain yang telah dibuat pada tahap desain.

4. Pengujian

Pengujian fokus pada perangkat lunak secara dari segi lojik dan fungsional dan memastikan bahwa semua bagian sudah diuji. Hal ini dilakukan untuk meminimalisir kesalahan (error) dan memastikan keluaran yang dihasilkan sesuai dengan yang diinginkan. 


\subsection{Analisis Teori Menentukan Pemain Sepak Bola Terbaik}

Algoritma tahapan penyelesaian metode Simple Additive Weighting (SAW) menurut Dicky dan Sarjon (2017:33), yaitu sebagai berikut :

1. Langkah 1 : Mendefinisikan terlebih dahulu kriteria-kriteria yang akan dijadikan sebagai tolak ukur penyelesaian masalah.

2. Langkah 2 : Menormalisasi setiap nilai alternatif pada setiap atribut dengan cara menghitung nilai rating kinerja.

3. Langkah 3 : Menghitung nilai bobot preferensi pada setiap alternatif.

4. Langkah 4 : Melakukan perangkingan.

\section{HASIL DAN PEMBAHASAN}

\subsection{Analisis Permasalahan}

Kompetisi sepak bola di Indonesia seringkali diwarnai hal-hal kontroversial, salah satunya ketika penyelenggara kompetisi tidak sesuai dalam mengambil keputusan untuk menentukan pemain terbaik, pengambilan keputusan dalam melakukan penilaian pemain terbaik ini masih dilakukan dengan cara manual, dan berdasarkan subjektifitas, karena belum menggunakan sistem serta metode sebagai dasar penilaian pemain terbaik.

\subsection{Analisis Kriteria dan Penilaian}

Penyelenggara kompetisi mempunyai 3 (tiga) aspek sebagai acuan untuk menentukan pemain terbaik yaitu aspek fairplay, kemampuan individu, dan kontribusi pada tim. Dari ketiga aspek tersebut kemudian akan ditentukan kriteria-kriteria sebagai penilaian untuk menentukan pemain terbaik, ada 9 kriteria yang dijadikan penilaian, dari 9 kriteria tersebut akan dikategorikan sesuai dengan posisi pemain. Penilaian dan pembobotan pada kriteria-kriteria ini menggunakan skala likert dengan bobot 1 (satu) sampai 5 (lima), dari mulai sangat kurang, hingga sangat baik. Berikut adalah kriteriakriteria yang digunakan untuk menentukan pemain terbaik :

1. Gol

Gol merupakan keberhasilan pemain ketika memasukan bola ke gawang lawan. Kriteria ini dimiliki pemain yang berposisi sebagai penyerang dan gelandang. Gol termasuk dalam kriteria beratribut benefit, artinya semakin banyak gol yang dihasilkan maka akan semakin bagus penilaian pada pemain tersebut, sebaliknya jika gol yang 
dihasilkan sedikit maka penilaian pada pemain tersebut pun akan kecil, untuk bobot gol pada posisi penyerang adalah 5, sedangkan pada posisi gelandang adalah 4 .

2. Assist

Assist merupakan umpan atau operan yang menghasilkan gol, kriteria ini dimiliki oleh pemain yang berposisi sebagai penyerang dan gelandang. Assist termasuk dalam kriteria beratribut benefit, artinya semakin banyak assist yang dihasilkan maka akan semakin bagus penilaian pada pemain tersebut, sebaliknya jika assist yang dihasilkan sedikit maka penilaian pada pemain tersebut pun akan kecil, untuk bobot assist pada posisi penyerang adalah 4 , sedangkan pada posisi gelandang adalah 5 .

3. Blok

Blok merupakan keberhasilan pemain dalam memblok tembakan ataupun mengahadang datangnya bola ketika akan masuk ke gawang, kriteria ini dimiliki oleh pemain yang berposisi sebagai bek. Blok termasuk dalam kriteria beratribut benefit, artinya semakin banyak blok yang dihasilkan maka akan semakin bagus penilaian pada pemain tersebut, sebaliknya jika blok yang dihasilkan sedikit maka penilaian pada pemain tersebut pun kecil. Kriteria blok memiliki nilai bobot 5 .

\section{Intercept}

Intercept adalah keberhasilan pemain ketika memotong umpan atau operan lawan, kriteria ini dimiliki oleh pemain yang berposisi sebagai gelandang dan bek. Intercept termasuk dalam kriteria beratribut benefit, artinya semakin banyak Intercept yang dihasilkan maka akan semakin bagus penilaian pada pemain tersebut, sebaliknya jika Intercept yang dihasilkan sedikit maka penilaian pada pemain tersebut pun kecil. Kriteria Intercept pada posisi gelandang memiliki nilai bobot 4, sedangkan pada posisi bek memiliki nilai bobot 5 .

\section{5. (Saves) Penyelamatan}

Saves atau penyelamatan adalah keberhasilan penjaga gawang dalam usahanya mengamankan gawang dari kebobolan. Penyelamatan termasuk dalam kriteria beratribut benefit, artinya semakin banyak penyelamatan yang dihasilkan oleh penjaga gawang maka akan semakin bagus penilaiannya, sebaliknya jika penyelamatan yang dihasilkan sedikit maka penilaian pada penjaga gawang tersebut pun kecil. Kriteria penyelamatan memiliki nilai bobot 5 . 


\section{Menit Bermain}

Menit bermain merupakan catatan seberapa banyak pemain bertanding, kriteria ini dimiliki oleh semua posisi pemain. Menit bermain termasuk dalam kriteria beratribut benefit, artinya semakin banyak menit bermain yang dihasilkan maka akan semakin bagus penilaian pada pemain tersebut, sebaliknya jika menit bermain yang dihasilkan sedikit maka penilaian pada pemain tersebut pun akan kecil. Kriteria menit bermain memiliki nilai bobot 4 .

\section{Kebobolan}

Kebobolan merupakan catatan seberapa banyak penjaga gawang kemasukan gol. Kebobolan termasuk dalam kriteria beratribut cost, artinya semakin sedikit kebobolan maka akan semakin bagus penilaiannya, sebaliknya jika catatan kebobolan banyak maka penilaian pada penjaga gawang tersebut pun kecil. Kriteria kebobolan memiliki nilai bobot 5 .

\section{Kartu Kuning}

Kartu kuning merupakan kartu yang dikeluarkan wasit kepada pemain akibat dari tindakan pemain yang melakukan pelanggaran cukup keras ataupun melakukan tindakan yang dilarang dalam pertandingan, kriteria ini dimiliki oleh pemain disemua posisi. Kartu kuning termasuk dalam kriteria beratribut cost, artinya semakin sedikit catatan kartu kuning pada pemain maka akan semakin bagus penilaiannya, sebaliknya jika catatan kartu kuning banyak maka penilaian pada pemain tersebut pun kecil. Kriteria kartu kuning memiliki nilai bobot 3 .

\section{Kartu Merah}

Kartu merah merupakan kartu yang dikeluarkan wasit kepada pemain akibat dari tindakan pemain yang melakukan pelanggaran sangat keras (fatal) ataupun melakukan tindakan yang sangat dilarang dalam pertandingan, kriteria ini dimiliki oleh pemain disemua posisi. Kartu merah termasuk dalam kriteria beratribut cost, artinya semakin sedikit catatan kartu merah pada pemain maka akan semakin bagus penilaiannya, sebaliknya jika catatan kartu merah banyak maka penilaian pada pemain tersebut pun kecil. Kriteria kartu merah memiliki nilai bobot 3.

Berdasarkan apa yang sudah dipaparkan, maka kriteria dan penilaian dapat dirangkum pada tabel sebagai berikut : 
TABEL : 3.1. Tabel Kriteria Penyerang

\begin{tabular}{|c|c|c|c|}
\hline Kode Kriteria & Nama Kriteria & Atribut & Bobot \\
\hline C1 & Gol & Benefit & 5 \\
\hline C2 & Assist & Benefit & 4 \\
\hline C3 & Menit Bermain & Benefit & 4 \\
\hline C4 & Kartu Kuning & Cost & 3 \\
\hline C5 & Kartu Merah & Cost & 3 \\
\hline
\end{tabular}

Pada tabel 3.1. memperlihatkan kriteria-kriteria pada pemain yang berposisi sebagai penyerang, penilaian bobot menggunakan skala likert dari 1 (satu) sampai 5 (lima).

TABEL : 3.2. Tabel Kriteria Gelandang

\begin{tabular}{|c|c|c|c|}
\hline Kode Kriteria & Nama Kriteria & Atribut & Bobot \\
\hline C1 & Gol & Benefit & 4 \\
\hline C2 & Assist & Benefit & 5 \\
\hline C3 & Intercept & Benefit & 4 \\
\hline C4 & Menit Bermain & Benefit & 4 \\
\hline C5 & Kartu Kuning & Cost & 3 \\
\hline C6 & Kartu Merah & Cost & 3 \\
\hline
\end{tabular}

Pada tabel 3.2. memperlihatkan kriteria-kriteria pada pemain yang berposisi sebagai gelandang, penilaian bobot menggunakan skala likert dari 1 (satu) sampai 5 (lima).

TABEL : 3.3. Tabel Kriteria Bek

\begin{tabular}{|c|c|c|c|}
\hline Kode Kriteria & Nama Kriteria & Atribut & Bobot \\
\hline C1 & Blok & Benefit & 5 \\
\hline C2 & Intercept & Benefit & 5 \\
\hline C3 & Menit Bermain & Benefit & 4 \\
\hline C4 & Kartu Kuning & Cost & 3 \\
\hline C5 & Kartu Merah & Cost & 3 \\
\hline
\end{tabular}

Pada tabel 3.3. memperlihatkan kriteria-kriteria pada pemain yang berposisi sebagai bek, penilaian bobot menggunakan skala likert dari 1 (satu) sampai 5 (lima).

TABEL : 3.4. Tabel Kriteria Penjaga Gawang

\begin{tabular}{|c|c|c|c|}
\hline Kode Kriteria & Nama Kriteria & Atribut & Bobot \\
\hline C1 & Saves (Penyelamatan) & Benefit & 5 \\
\hline C2 & Menit Bermain & Benefit & 4 \\
\hline C3 & Kebobolan & Benefit & 5 \\
\hline C4 & Kartu Kuning & Cost & 3 \\
\hline C5 & Kartu Merah & Cost & 3 \\
\hline
\end{tabular}


Pada tabel 3.4. memperlihatkan kriteria-kriteria pada pemain yang berposisi sebagai penjaga gawang, penilaian bobot menggunakan skala likert dari 1 (satu) sampai 5 (lima).

Setelah ditentukan kriteria-kriteria, atribut, dan nilai bobot yang digunakan untuk menilai pemain pada tiap posisi, selanjutnya menentukan himpunan nilai dari masingmasing kriteria tersebut, penilaiannya dengan menggunakan skala likert dari mulai sangat kurang hingga sangat baik, berikut adalah tabel himpunan kriteria pada tiap posisi pemain:

TABEL : 3.5. Tabel Himpunan Kriteria Penyerang

\begin{tabular}{|c|c|c|c|c|}
\hline Kode Kriteria & Nama Kriteria & Himpunan & Nilai & Keterangan \\
\hline \multirow{5}{*}{$\mathrm{C} 1$} & \multirow{5}{*}{ Gol } & $<10$ & 20 & Sangat Kurang \\
\hline & & $10-13$ & 40 & Kurang \\
\hline & & $14-17$ & 60 & Cukup \\
\hline & & $18-21$ & 80 & Baik \\
\hline & & $>21$ & 100 & Sangat Baik \\
\hline \multirow{5}{*}{$\mathrm{C} 2$} & \multirow{5}{*}{ Assist } & $<4$ & 20 & Sangat Kurang \\
\hline & & $4-6$ & 40 & Kurang \\
\hline & & $7-9$ & 60 & Cukup \\
\hline & & $10-12$ & 80 & Baik \\
\hline & & $>12$ & 100 & Sangat Baik \\
\hline \multirow{5}{*}{ C3 } & \multirow{5}{*}{ Menit Bermain } & $<1800$ Menit & 20 & Sangat Kurang \\
\hline & & $1800-2100$ Menit & 40 & Kurang \\
\hline & & $2101-2400$ Menit & 60 & Cukup \\
\hline & & $2401-2700$ Menit & 80 & Baik \\
\hline & & $>2700$ Menit & 100 & Sangat Baik \\
\hline \multirow{5}{*}{$\mathrm{C} 4$} & \multirow{5}{*}{ Kartu Kuning } & $<3$ & 20 & Sangat Baik \\
\hline & & $3-5$ & 40 & Baik \\
\hline & & $6-8$ & 60 & Cukup \\
\hline & & $9-11$ & 80 & Kurang \\
\hline & & $>11$ & 100 & Sangat Kurang \\
\hline \multirow{5}{*}{$\mathrm{C} 5$} & \multirow{5}{*}{ Kartu Merah } & 0 & 20 & Sangat Baik \\
\hline & & $1-2$ & 40 & Baik \\
\hline & & $3-4$ & 60 & Cukup \\
\hline & & $5-6$ & 80 & Kurang \\
\hline & & $>6$ & 100 & Sangat Kurang \\
\hline
\end{tabular}

Pada tabel 3.5. memperlihatkan nilai himpunan kriteria pada pemain yang berposisi sebagai penyerang, penilaiannya menggunakan skala likert dari sangat kurang, hingga sangat baik. 
TABEL : 3.6. Tabel Himpunan Kriteria Gelandang

\begin{tabular}{|c|c|c|c|c|}
\hline Kode Kriteria & Nama Kriteria & Himpunan & Nilai & Keterangan \\
\hline \multirow{5}{*}{$\mathrm{C} 1$} & \multirow{5}{*}{ Gol } & $<10$ & 20 & Sangat Kurang \\
\hline & & $10-13$ & 40 & Kurang \\
\hline & & $14-17$ & 60 & Cukup \\
\hline & & $18-21$ & 80 & Baik \\
\hline & & $>21$ & 100 & Sangat Baik \\
\hline \multirow{5}{*}{$\mathrm{C} 2$} & \multirow{5}{*}{ Assist } & $<4$ & 20 & Sangat Kurang \\
\hline & & $4-6$ & 40 & Kurang \\
\hline & & $7-9$ & 60 & Cukup \\
\hline & & $10-12$ & 80 & Baik \\
\hline & & $>12$ & 100 & Sangat Baik \\
\hline \multirow{5}{*}{ C3 } & \multirow{5}{*}{ Intercept } & $<20$ & 20 & Sangat Kurang \\
\hline & & $20-26$ & 40 & Kurang \\
\hline & & $27-33$ & 60 & Cukup \\
\hline & & $34-40$ & 80 & Baik \\
\hline & & $>40$ & 100 & Sangat Baik \\
\hline \multirow{5}{*}{$\mathrm{C} 4$} & \multirow{5}{*}{ Menit Bermain } & $<1800$ Menit & 20 & Sangat Kurang \\
\hline & & $1800-2100$ Menit & 40 & Kurang \\
\hline & & $2101-2400$ Menit & 60 & Cukup \\
\hline & & $2401-2700$ Menit & 80 & Baik \\
\hline & & $>2700$ Menit & 100 & Sangat Baik \\
\hline \multirow{5}{*}{ C5 } & \multirow{5}{*}{ Kartu Kuning } & $<3$ & 20 & Sangat Baik \\
\hline & & $3-5$ & 40 & Baik \\
\hline & & $6-8$ & 60 & Cukup \\
\hline & & $9-11$ & 80 & Kurang \\
\hline & & $>11$ & 100 & Sangat Kurang \\
\hline \multirow{5}{*}{ C6 } & \multirow{5}{*}{ Kartu Merah } & 0 & 20 & Sangat Baik \\
\hline & & $1-2$ & 40 & Baik \\
\hline & & $3-4$ & 60 & Cukup \\
\hline & & $5-6$ & 80 & Kurang \\
\hline & & $>6$ & 100 & Sangat Kurang \\
\hline
\end{tabular}

Pada tabel 3.6. memperlihatkan nilai himpunan kriteria pada pemain yang berposisi sebagai gelandang, penilaiannya menggunakan skala likert dari sangat kurang, hingga sangat baik. 
TABEL : 3.7. Tabel Himpunan Kriteria Bek

\begin{tabular}{|c|c|c|c|c|}
\hline Kode Kriteria & Nama Kriteria & Himpunan & Nilai & Keterangan \\
\hline \multirow{5}{*}{$\mathrm{C} 1$} & \multirow{5}{*}{ Blok } & $<15$ & 20 & Sangat Kurang \\
\hline & & $15-20$ & 40 & Kurang \\
\hline & & $21-25$ & 60 & Cukup \\
\hline & & $26-30$ & 80 & Baik \\
\hline & & $>30$ & 100 & Sangat Baik \\
\hline \multirow{5}{*}{$\mathrm{C} 2$} & \multirow{5}{*}{ Intercept } & $<20$ & 20 & Sangat Kurang \\
\hline & & $20-26$ & 40 & Kurang \\
\hline & & $27-33$ & 60 & Cukup \\
\hline & & $34-40$ & 80 & Baik \\
\hline & & $>40$ & 100 & Sangat Baik \\
\hline \multirow{5}{*}{$\mathrm{C} 4$} & \multirow{5}{*}{ Menit Bermain } & $<1800$ Menit & 20 & Sangat Kurang \\
\hline & & $1800-2100$ Menit & 40 & Kurang \\
\hline & & $2101-2400$ Menit & 60 & Cukup \\
\hline & & $2401-2700$ Menit & 80 & Baik \\
\hline & & $>2700$ Menit & 100 & Sangat Baik \\
\hline \multirow{5}{*}{ C5 } & \multirow{5}{*}{ Kartu Kuning } & $<3$ & 20 & Sangat Baik \\
\hline & & $3-5$ & 40 & Baik \\
\hline & & $6-8$ & 60 & Cukup \\
\hline & & $9-11$ & 80 & Kurang \\
\hline & & $>11$ & 100 & Sangat Kurang \\
\hline \multirow{5}{*}{ C6 } & \multirow{5}{*}{ Kartu Merah } & 0 & 20 & Sangat Baik \\
\hline & & $1-2$ & 40 & Baik \\
\hline & & $3-4$ & 60 & Cukup \\
\hline & & $5-6$ & 80 & Kurang \\
\hline & & $>6$ & 100 & Sangat Kurang \\
\hline
\end{tabular}

Pada tabel 3.7. memperlihatkan nilai himpunan kriteria pada pemain yang berposisi sebagai bek, penilaiannya menggunakan skala likert dari sangat kurang, hingga sangat baik.

TABEL : 3.8. Tabel Himpunan Kriteria Penjaga Gawang

\begin{tabular}{|c|c|c|c|c|}
\hline Kode Kriteria & Nama Kriteria & Himpunan & Nilai & Keterangan \\
\hline \multirow{4}{*}{ C1 } & \multirow{3}{*}{$\begin{array}{c}\text { Saves } \\
\text { (Penyelamatan) }\end{array}$} & $<50$ & 20 & Sangat Kurang \\
\cline { 3 - 5 } & & $50-65$ & 40 & Kurang \\
\cline { 3 - 5 } & & $86-80$ & 60 & Cukup \\
\cline { 3 - 5 } & & $>95$ & 80 & Baik \\
\hline \multirow{5}{*}{ C2 } & \multirow{4}{*}{ Menit Bermain } & $<1800$ Menit & 20 & Sangat Kurang \\
\cline { 3 - 5 } & & $1800-2100$ Menit & 40 & Kurang \\
\cline { 3 - 5 } & & $2101-2400$ Menit & 60 & Cukup \\
\cline { 3 - 5 } & & $2401-2700$ Menit & 80 & Baik \\
\cline { 3 - 5 } & & $>2700$ Menit & 100 & Sangat Baik \\
\hline
\end{tabular}




\begin{tabular}{|c|c|c|c|c|}
\hline Kode Kriteria & Nama Kriteria & Himpunan & Nilai & Keterangan \\
\hline \multirow{5}{*}{$\mathrm{C} 3$} & \multirow{5}{*}{ Kebobolan } & $<25$ & 20 & Sangat Baik \\
\hline & & $25-35$ & 40 & Baik \\
\hline & & $36-45$ & 60 & Cukup \\
\hline & & $46-55$ & 80 & Kurang \\
\hline & & $>55$ & 100 & Sangat Kurang \\
\hline \multirow{5}{*}{$\mathrm{C} 5$} & \multirow{5}{*}{ Kartu Kuning } & $<3$ & 20 & Sangat Baik \\
\hline & & $3-5$ & 40 & Baik \\
\hline & & $6-8$ & 60 & Cukup \\
\hline & & $9-11$ & 80 & Kurang \\
\hline & & $>11$ & 100 & Sangat Kurang \\
\hline \multirow{5}{*}{ C6 } & \multirow{5}{*}{ Kartu Merah } & 0 & 20 & Sangat Baik \\
\hline & & $1-2$ & 40 & Baik \\
\hline & & $3-4$ & 60 & Cukup \\
\hline & & $5-6$ & 80 & Kurang \\
\hline & & $>6$ & 100 & Sangat Kurang \\
\hline
\end{tabular}

Pada tabel 3.8. memperlihatkan nilai himpunan kriteria pada pemain yang berposisi sebagai penjaga gawang, penilaiannya menggunakan skala likert dari sangat kurang, hingga sangat baik.

\subsection{Desain}

\subsubsection{Penyelesaian Dengan Metode Simple Additive Weighting (SAW)}

Pada poin ini akan dipaparkan penyelesaian dengan metode Simple Additive Weighting (SAW). Penulis hanya mencari pemain terbaik pada posisi penyerang saja, karena langkah penyelesaian dan rumus perhitungannya tidak berbeda pada tiap posisi pemain.

Sesuai dengan yang telah dipaparkan pada landasan teori di BAB II, Menurut Dicky dan Sarjon (2017:33), algoritma tahapan penyelesaian metode SAW yaitu sebagai berikut :

1. Langkah 1 : Mendefinisikan terlebih dahulu kriteria-kriteria yang akan dijadikan sebagai tolak ukur penyelesaian masalah.

2. Langkah 2 : Menormalisasi setiap nilai alternatif pada setiap atribut dengan cara menghitung nilai rating kinerja.

3. Langkah 3 : Menghitung nilai bobot preferensi pada setiap alternatif.

4. Langkah 4 : Melakukan perangkingan. 


\subsubsection{Mendefinisikan Kriteria}

Langkah pertama dalam penyelesaian menggunakan metode SAW yaitu mendefinisikan terlebih dahulu kriteria-kriteria yang akan digunakan. Seperti yang sudah dipaparkan pada poin sebelumnya mengenai analisis kriteria dan penilaian, kriteriakriteria yang digunakan untuk menentukan pemain terbaik pada posisi penyerang, yaitu sebagai berikut :

\section{TABEL : 3.9. Tabel Kriteria Penyerang}

\begin{tabular}{|c|c|c|c|}
\hline Kode Kriteria & Nama Kriteria & Atribut & Bobot \\
\hline C1 & Gol & Benefit & 5 \\
\hline C2 & Assist & Benefit & 4 \\
\hline C3 & Menit Bermain & Benefit & 4 \\
\hline C4 & Kartu Kuning & Cost & 3 \\
\hline C5 & Kartu Merah & Cost & 3 \\
\hline
\end{tabular}

Pada tabel 3.9. memperlihatkan kriteria-kriteria pada pemain yang berposisi sebagai penyerang, penilaian bobot menggunakan skala likert dari 1 (satu) sampai 5 (lima).

Setelah ditentukan kriteria-kriteria, atribut, dan nilai bobot yang digunakan, selanjutnya adalah menentukan himpunan nilai dari masing-masing kriteria tersebut, penilaian yang digunakan menggunakan skala likert dari mulai sangat kurang hingga sangat baik. Tabel himpunan kriteria pada pemain yang berposisi sebagai penyerang adalah sebagai berikut :

TABEL : 3.10. Tabel Himpunan Kriteria Penyerang

\begin{tabular}{|c|c|c|c|c|}
\hline Kode Kriteria & Nama Kriteria & Himpunan & Nilai & Keterangan \\
\hline \multirow{5}{*}{$\mathrm{C} 1$} & \multirow{5}{*}{ Gol } & $<10$ & 20 & Sangat Kurang \\
\hline & & $10-13$ & 40 & Kurang \\
\hline & & $14-17$ & 60 & Cukup \\
\hline & & $18-21$ & 80 & Baik \\
\hline & & $>21$ & 100 & Sangat Baik \\
\hline \multirow{5}{*}{$\mathrm{C} 2$} & \multirow{5}{*}{ Assist } & $<4$ & 20 & Sangat Kurang \\
\hline & & $4-6$ & 40 & Kurang \\
\hline & & $7-9$ & 60 & Cukup \\
\hline & & $10-12$ & 80 & Baik \\
\hline & & $>12$ & 100 & Sangat Baik \\
\hline \multirow{5}{*}{ C3 } & \multirow{5}{*}{ Menit Bermain } & $<1800$ Menit & 20 & Sangat Kurang \\
\hline & & $1800-2100$ Menit & 40 & Kurang \\
\hline & & $2101-2400$ Menit & 60 & Cukup \\
\hline & & $2401-2700$ Menit & 80 & Baik \\
\hline & & $>2700$ Menit & 100 & Sangat Baik \\
\hline
\end{tabular}




\begin{tabular}{|c|c|c|c|c|}
\hline Kode Kriteria & Nama Kriteria & Himpunan & Nilai & Keterangan \\
\hline \multirow{4}{*}{ C4 } & \multirow{4}{*}{ Kartu Kuning } & $<3$ & 20 & Sangat Baik \\
\cline { 3 - 5 } & & $3-5$ & 40 & Baik \\
\cline { 3 - 5 } & & $6-8$ & 60 & Cukup \\
\cline { 3 - 5 } & & $9-11$ & 80 & Kurang \\
\cline { 3 - 5 } & & $>11$ & 100 & Sangat Kurang \\
\hline \multirow{4}{*}{ C5 } & \multirow{4}{*}{ Kartu Merah } & $1-2$ & 20 & Sangat Baik \\
\cline { 3 - 5 } & & $3-4$ & 60 & Baik \\
\cline { 3 - 5 } & & $5-6$ & 80 & Cukup \\
\cline { 3 - 5 } & & $>6$ & 100 & Sangat Kurang \\
\hline
\end{tabular}

Pada tabel 3.10. memperlihatkan nilai himpunan kriteria pada pemain yang berposisi sebagai penyerang, penilaiannya menggunakan skala likert dari sangat kurang, hingga sangat baik.

Setelah ditentukan kriteria-kriteria, beserta dengan himpunannya, selanjutnya adalah melakukan klasifikasi data pemain. Data pemain yang digunakan merujuk pada catatan statistik pemain selama berlaga dikompetisi liga 1, musim 2018. Data statistik kandidat pemain terbaik pada posisi penyerang adalah sebagai berikut :

TABEL : 3.11. Tabel Data Statistik Penyerang

\begin{tabular}{|c|c|c|c|c|c|}
\hline $\begin{array}{c}\text { Nama Pemain } \\
\text { (Kode Alternatif) }\end{array}$ & $\begin{array}{c}\text { Gol } \\
\text { (C1) }\end{array}$ & $\begin{array}{c}\text { Assist } \\
\text { (C2) }\end{array}$ & $\begin{array}{c}\text { Menit } \\
\text { Bermain } \\
\text { (C3) }\end{array}$ & $\begin{array}{c}\text { Kartu } \\
\text { Kuning } \\
\text { (C4) }\end{array}$ & $\begin{array}{c}\text { Kartu } \\
\text { Merah } \\
\text { (C5) }\end{array}$ \\
\hline Aleksandar Rakic (A1) & 21 & 3 & 3.060 & 2 & 0 \\
\hline David Da Silva (A2) & 20 & 3 & 1.594 & 3 & 0 \\
\hline Ezechiel Ndouassel (A3) & 17 & 5 & 1.980 & 8 & 0 \\
\hline
\end{tabular}

Pada tabel 3.11. memperlihatkan nama pemain, kode alternatif, dan data catatan statistik kandidat pemain terbaik pada posisi penyerang dalam 1 (satu) musim kompetisi liga 12018.

Setelah mendapatkan data catatan statistik pemain, selanjutnya adalah melakukan klasifikasi atau disebut juga dengan matriks keputusan. Klasifikasi yang dimaksud yaitu menilai hasil yang ditorehkan oleh pemain berdasarkan himpunan kriteria yang telah ditentukan. Berikut adalah hasil klasifikasi dari data statistik pemain tersebut : 
TABEL : 3.12. Tabel Data Klasifikasi Penyerang

\begin{tabular}{|r|c|c|c|c|c|}
\hline & C1 & C2 & C3 & C4 & C5 \\
\hline A1 & 80 & 20 & 100 & 20 & 20 \\
\hline A2 & 80 & 20 & 20 & 40 & 20 \\
\hline A3 & 60 & 40 & 40 & 60 & 20 \\
\hline
\end{tabular}

Pada tabel 3.12. memperlihatkan data klasifikasi penilaian hasil catatan statistik yang ditorehkan oleh pemain berdasarkan himpunan kriteria yang telah ditentukan.

\subsubsection{Normalisasi}

Setelah mendefinisikan kriteria dan memperoleh data klasifikasi, langkah berikutnya yaitu melakukan normalisasi, rumus yang digunakan adalah sebagai berikut :

$$
r_{i j}=\left\{\begin{array}{ll}
\frac{x_{i j}}{\operatorname{Max} x_{i j}} & j i k a \mathrm{j} \text { adalah atribut keuntungan (benefit) } \\
\frac{\operatorname{Min}_{i} x_{i j}}{x_{i j}} & \text { jika } \mathrm{j} \text { adalah atribut biay a (cost) }
\end{array}\right]
$$

Keterangan :

- $\quad \mathrm{Rij}=$ Nilai rating kinerja ternormalisasi.

- $\quad \mathrm{Xij}=$ Nilai atribut yang dimiliki dari setiap kriteria.

- $\quad$ Max Xij = Nilai terbesar dari setiap kriteria.

- $\quad$ Min $\mathrm{Xij}=$ Nilai terkecil dari setiap kriteria

- $\quad$ Benefit $=$ Jika nilai terbesar adalah nilai terbaik

- $\quad C o s t=$ Jika nilai terkecil adalah nilai terbaik

Dari rumus tersebut akan dihitung normalisasi dari data klasifikasi sesuai dengan atribut pada kriteria-kriteria yang digunakan, yaitu sebagai berikut :

1. Pada kriteria gol (C1), kriteria ini mempunyai atribut benefit, maka perhitungannya adalah sebagai berikut :
- $\mathrm{R}_{11}=$
$80 \quad=80 / 80=1$
$\operatorname{Max}\{80,80,60\}$
- $\mathrm{R}_{21}=\frac{80}{208 / 80=1}$
$\operatorname{Max}\{80,80,60\}$ 
- $\mathrm{R}_{31}=$ $60 \quad=60 / 80=0,75$

$\operatorname{Max}\{80,80,60\}$

2. Pada kriteria assist (C2), kriteria ini mempunyai atribut benefit, maka perhitungannya adalah sebagai berikut :

- $\mathrm{R}_{12}=$

$20=20 / 40=0,5$

$\operatorname{Max}\{20,20,40\}$

- $\mathrm{R}_{22}=$

$$
20=20 / 40=0,5
$$

$\operatorname{Max}\{20,20,40\}$

- $\mathrm{R}_{22}=$

$$
40 \quad=40 / 40=1
$$

$\operatorname{Max}\{20,20,40\}$

3. Pada kriteria menit bermain (C3), kriteria ini mempunyai atribut benefit, maka perhitungannya adalah sebagai berikut :

- $\mathrm{R}_{13}=\frac{100}{=100 / 100=1}$

$\operatorname{Max}\{100,20,40\}$

- $\mathrm{R}_{23}=$ $=20 / 100=0,2$

$\operatorname{Max}\{100,20,40\}$

- $\mathrm{R}_{33}=$

$$
40=40 / 100=0,4
$$

$\operatorname{Max}\{100,20,40\}$

4. Pada kriteria kartu kuning (C4), kriteria ini mempunyai atribut cost, maka perhitungannya adalah sebagai berikut :

- $\mathrm{R}_{14}=\underline{\operatorname{Min}\{20,40,60\}}=20 / 20=1$

20

- $\mathrm{R}_{24}=\underline{\operatorname{Min}}\{20,40,60\}=20 / 40=0,5$

40

- $\mathrm{R}_{34}=\underline{\operatorname{Min}\{20,40,60\}}=20 / 60=0,33$

60

5. Pada kriteria kartu merah (C5), kriteria ini mempunyai atribut cost, maka perhitungannya adalah sebagai berikut : 
- $\mathrm{R}_{15}=\underline{\operatorname{Min}}\{20,20,20\}=20 / 20=1$

20

- $\mathrm{R}_{25}=\underline{\operatorname{Min}\{20,20,20\}}=20 / 20=1$

20

- $\mathrm{R}_{35}=\underline{\operatorname{Min}\{20,20,20\}}=20 / 20=1$

20

Dari hasil perhitungan normalisasi tersebut kemudian dibuat tabel normalisasinya, sebagai berikut :

TABEL : 3.13. Tabel Normalisasi Penyerang

\begin{tabular}{|r|c|c|c|c|c|}
\hline & C1 & C2 & C3 & C4 & C5 \\
\hline A1 & 1 & 0,5 & 1 & 1 & 1 \\
\hline A2 & 1 & 0,5 & 0,2 & 0,5 & 1 \\
\hline A3 & 0,75 & 1 & 0,4 & 0,33 & 1 \\
\hline
\end{tabular}

Pada tabel 3.13. memperlihatkan data hasil perhitungan normalisasi dari tabel klasifikasi yang sudah diperoleh sebelumnya.

\subsubsection{Kalkulasi Pembobotan}

Langkah berikutnya setelah melakukan normalisasi yaitu menghitung nilai bobot preferensi pada setiap alternatif, rumus yang digunakan adalah sebagai berikut :

$$
V_{i}=\sum_{j=1}^{n} w_{j} r_{i j}
$$

Keterangan :

$\mathrm{Vi}=$ ranking untuk setiap alternatif.

$\mathrm{Wj}=$ nilai bobot dari setiap kriteria.

$\mathrm{Rij}=$ nilai rating kinerja ternormalisasi .

Dari rumus tersebut akan dihitung ranking untuk setiap alternatif (Vi) sesuai hasil pada tabel normalisasi dan bobot kriteria yang sudah ditentukan, perhitungannya sebagai berikut : 
1. Nilai ranking pada A1 :

$$
\begin{aligned}
\mathrm{V} 1 & =\left(\mathrm{W}_{1} * \mathrm{R}_{11}\right)+\left(\mathrm{W}_{2} * \mathrm{R}_{12}\right)+\left(\mathrm{W}_{3} * \mathrm{R}_{13}\right)+\left(\mathrm{W}_{4} * \mathrm{R}_{14}\right)+\left(\mathrm{W}_{5} * \mathrm{R}_{15}\right) \\
& =(5 * 1)+(4 * 0,5)+(4 * 1)+(3 * 1)+(3 * 1) \\
& =5+2+4+3+3 \\
& =17
\end{aligned}
$$

2. Nilai ranking pada $\mathrm{A} 2$ :

$$
\begin{aligned}
\mathrm{V} 2 & =\left(\mathrm{W}_{1} * \mathrm{R}_{21}\right)+\left(\mathrm{W}_{2} * \mathrm{R}_{22}\right)+\left(\mathrm{W}_{3} * \mathrm{R}_{23}\right)+\left(\mathrm{W}_{4} * \mathrm{R}_{24}\right)+\left(\mathrm{W}_{5} * \mathrm{R}_{25}\right) \\
& =(5 * 1)+(4 * 0,5)+(4 * 0,2)+(3 * 0,5)+(3 * 1) \\
& =5+2+0,8+1,5+3 \\
=12,3 &
\end{aligned}
$$

3. Nilai ranking pada $\mathrm{A} 3$ :

$$
\begin{aligned}
\mathrm{V} 3 & =\left(\mathrm{W}_{1} * \mathrm{R}_{31}\right)+\left(\mathrm{W}_{2} * \mathrm{R}_{32}\right)+\left(\mathrm{W}_{3} * \mathrm{R}_{33}\right)+\left(\mathrm{W}_{4} * \mathrm{R}_{34}\right)+\left(\mathrm{W}_{5} * \mathrm{R}_{35}\right) \\
& =(5 * 0,75)+(4 * 1)+(4 * 0,4)+(3 * 0,33)+(3 * 1) \\
& =3,75+4+1,6+0,99+3 \\
& =13,34
\end{aligned}
$$

\subsubsection{Perankingan}

Langkah selanjutnya setelah melakukan pembobotan adalah menentukan perankingan, yaitu menentukan nilai Vi tertinggi dari setiap alternatif, yaitu sebagai berikut :

TABEL: 3.14. Tabel Perankingan Penyerang

\begin{tabular}{|c|c|c|}
\hline $\begin{array}{c}\text { Nama Pemain } \\
\text { (Kode Alternatif) }\end{array}$ & Nilai Ranking (Vi) & Keterangan \\
\hline Aleksandar Rakic (A1) & 17 & Ranking 1 \\
\hline David Da Silva (A2) & 12,3 & Ranking 3 \\
\hline Ezechiel Ndouassel (A3) & 13,34 & Ranking 2 \\
\hline
\end{tabular}

Pada tabel 3.14. memperlihatkan data hasil perankingan pemain, dari data tersebut didapatkan bahwa pemain terbaik pada posisi penyerang adalah Aleksander Rakic yang memiliki nilai 17. 


\subsection{Pengujian}

Pengujian terhadap sistem menggunakan Blackbox, yaitu menguji semua fungsi input dan output dari mendefinisikan kriteria-kriteria, menormalisasi setiap nilai alternatif, menghitung nilai bobot preferensi pada setiap alternatif, dan melakukan perangkingan.

\section{KESIMPULAN}

Kesimpulan dari penelitian ini adalah :

1. Pengambilan keputusan untuk menentukan pemain terbaik dapat dilakukan dengan cara sistematis, dan dengan diterapkannya sistem pendukung keputusan ini maka akan mengurangi subyektifitas penyelenggara kompetisi dalam menentukan pemain terbaik, sehingga keputusan yang dihasilkan sesuai, tepat, dan akurat.

2. Selain untuk penyelenggara kompetisi tentunya klub-klub sepakbola pun dapat menggunakan aplikasi sistem pendukung keputusan ini untuk menentukan pemain yang akan mereka rekrut.

\section{DAFTAR PUSTAKA}

Agus Rahadi. (2017) : Perbandingan Metode Analytical Process Dengan Metode Simple Additive Weighting Untuk Perekrutan Dosen Pada IBI Darmajaya Lampung. ISSN 2087-2062. Tersedia di http://jurnal.ubl.ac.id/index.php/explore/article/view/864/884 Diakses 8 April 2019.

Aripin, dkk., (2018) : Sistem Pendukung Keputusan Pemilihan Bibit Mangga Terunggul Menerapkan Metode SAW dan WASPAS. ISBN: 978-602-52720-0-4. Tersedia di : http://prosiding.seminar-id.com/index.php/sensasi/article/view/76/76 Diakses 8 April 2019.

Arjon Samuel. (2017) : Sistem Pendukung Keputusan Penentuan Supplier Pembelian Barang Menggunakan Metode Analitical Hierarchy Process Pada PT Perintis Sarana Pancing Indonesia. Journal of Informatic Pelita Nusantara Vol.2 No.1. Tersedia di : e-jurnal.pelitanusantara.ac.id/index.php/JIPN/article/download/297/194 Diakses 8 April 2019.

Avina, dkk., (2018) : Implementasi Metode Simple Additive Weighting (SAW) dan Weight Product (WP) Dalam Pemilihan Guru Teladan (Studi Kasus : MI Ma'Arif NU 1 Ajibarang Wetan). ISBN: 978-979-3649-99-3. Tersedia di : https://www.unisbank.ac.id/ojs/index.php/sendi_u/article/view/5991

Diakses 8 April 2019. 
Betha Sidik. (2017) : Pemograman Web dengan PHP 7. Bandung : INFORMATIKA.

Budi Raharjo. (2016) : Modul Pemograman WEB (HTML, PHP, \& MySQL) Edisi Ketiga. Bandung : Modula.

Dicky Nofriansyah dan Sarjon Defit. (2017): Multi Criteria Desiciton Making (MCDM) Pada Sistem Pendukung Keputusan. Yogyakarta : Deepublish.

Diqy dan Ervan. (2017) : Analisis Perbandingan Metode AHP dan SAW Dalam Penilaian Kinerja Karyawan (Studi Kasus di PT. Grafindo Media Pratama Bandung). JURNAL LPKIA, Vol.10 No.2, Desember 2017. Tersefia di : http://jurnal.lpkia.ac.id/index.php/jkb/article/view/125

Diakses 8 April 2019

Elisabeth Yunaeti Anggraeni dan Rita Irviani. (2017): Pengantar Sistem Informasi. Yogyakarta: Andi Offset.

Fathansyah. (2018) : Basis Data. Bandung : INFORMATIKA. Edisi Revisi Ketiga.

Fathur Rohman (2017) : Pendidikan Jasmani, Olahraga, dan Kesehatan. Jakarta : PT. Bumi Aksara.

Harold Situmorang. (2015) : Sistem Pendukung Keputusan Pemilihan Calon Peserta Olimpiade Sains Tingkat Kabupaten Langkat Pada Madrasah Aliyah Negeri (MAN) 2 Tanjung Pura Dengan Menggunakan Metode Simple Additive Weighting (SAW). Jurnal TIMES , Vol. IV No 2. Tersedia di :

http://www.stmik-time.ac.id/ejournal/index.php/jurnalTIMES/article/viewFile/230/94

Diakses 8 April 2019

Jeperson Hutahean. (2014) : Konsep Sistem Informasi. Yogyakarta : Deepublish.

Maniah dan Dini Hamdani. (2017) : Analisis dan Perancangan Sistem Informasi. Yogyakarta : DEEPUBLISH.

Marshall B. Romney, dan Paul John Steinbart. (2015): Sistem Informasi Akuntansi, Edisi 13. Jakarta: Salemba Empat.

Muhamad Muslihudin dan Oktafianto. (2016): Analisis dan Perancangan Sistem Informasi Menggunakan Model Terstruktur dan UML. Yogyakarta : CV ANDI OFFSET.

Nardiono. (2017) : Komparasi metode Simple Additive Weighting (SAW) dan Metode Weighted Product (WP) Dalam menentukan Karyawan Terbaik (Studi Kasus: PT. Matrixnet Global Indonesia). ISSN 2541-1004. Tersedia di : https://www.neliti.com/publications/261255/komparasi-metode-simple-additiveweightin-saw-dan-metode-weighted-product-wp-dal Diakses 8 April 2019 
Priyanto Hidayatullah dan Jauhari Khairul. (2017) : Pemograman Web. Bandung : INFORMATIKA.

RH. Sianipar. (2015) : HTML 5 dan CSS 3. Bandung : INFORMATIKA.

Rohingun. (2015) : Smart Trik Jquery Without Plugin. Yogyakarta : CV ANDI OFFSET.

Rosa A.S dan M.Salahuddin. (2018) : Rekayasa Perangkat Lunak Terstruktur dan Berorientasi Objek. Bandung : INFORMATIKA.

Wawan, dkk., (2017) : Membangun Nasionalisme Dari Sepakbola (Studi Pembinaan Sepakbola Usia Dini Untuk Membangun Karakter Nasionalis Di Kota Madiun). Lembaga Penelitian dan Pengabdian kepada Masyarakat UNIPMA. Tersedia di : http://prosiding.unipma.ac.id/index.php/SNHP/article/view/56 Diakses 8 April 2019.

Witanti, dkk., (2016) : Pembangunan Sistem Temu Balik Informasi (Information Retrieval) Dalam Pemilihan Pemain Sepakbola Berkualitas Di Indonesia Berbasis Analisis Sentimen. Seminar Nasional Teknologi Informasi dan Komunikasi 2016 (SENTIKA 2016).

Tersedia di : https://fti.uajy.ac.id/sentika/publikasi/makalah/2016/34.pdf Diakses 8 April 2019. 